\section{Ecophysiology germination of Senna uniflora seeds: species for recovery degraded areas}

\author{
Jullyanna Nair de Carvalho ${ }^{1 *}$ (D), Márkilla Zunete Beckmann Cavalcante ${ }^{2}$ iD, \\ Pollyanna Aparecida de Carvalho ${ }^{1}$ iD, Daniel Salgado Pifano ${ }^{3}$ iD, Renato \\ Garcia Rodrigues ${ }^{3}$
}

\begin{abstract}
Studies on seeds ecophysiology are important to understanding of adaptation mechanisms and of species' tolerance limits to natural conditions, because determine the potential of use in recovery plans of degraded areas. The aim of this study was to characterize and assess the effect of different temperatures, methods of dormancy overcoming and water and salt stresses on the germination of Senna uniflora. Imbibition curve and germination assay were conducted to assess the effect of temperature regimes $\left(20{ }^{\circ} \mathrm{C}, 25^{\circ} \mathrm{C}, 30^{\circ} \mathrm{C}\right.$, $35{ }^{\circ} \mathrm{C}, 40{ }^{\circ} \mathrm{C}$ and $20-30{ }^{\circ} \mathrm{C}$ ), of methods of overcoming dormancy (without scarification, mechanical scarification, chemical scarification and thermal scarification) and of water and salt stresses at the osmotic potentials $(0.0 ;-0.2 ;-0.4$ and $-0.8 \mathrm{MPa})$. The assessed variables were germination, germination speed index and average germination time. Methods of mechanical and chemical scarification for 5, 15 and $30 \mathrm{~min}$ were efficient to overcome physical dormancy, especially on constant temperature regimes of $25{ }^{\circ} \mathrm{C}$ and $30{ }^{\circ} \mathrm{C}$ and alternated $20-30^{\circ} \mathrm{C}$. Submitted to conditions of water and salt stresses, seeds germination was reduced with the increase of the osmotic potential, being $-0.8 \mathrm{MPa}$ the germination minimum limit, in addition, seeds were more sensitive to water stress than to salt stress.
\end{abstract}

Index terms: seeds dormancy, pioneer species, temperature, water stress, salt stress.

\section{Ecofisiologia da germinação de sementes de Senna uniflora: uma espécie para recuperação de áreas degradadas}

RESUMO: Estudos sobre a ecofisiologia das sementes são importantes para compreender os mecanismos de adaptação e os limites de tolerância das espécies às condições naturais, pois determinam seu potencial uso em recuperação de áreas degradadas. Objetivou-se neste estudo caracterizar e avaliar o efeito de diferentes temperaturas, métodos de superação de dormência e estresses hídrico e salino na germinação de Senna uniflora. Realizou-se curva de embebição e testes de germinação para avaliar o efeito dos regimes de temperatura $\left(20^{\circ} \mathrm{C}, 25^{\circ} \mathrm{C}, 30^{\circ} \mathrm{C}, 35^{\circ} \mathrm{C}, 40^{\circ} \mathrm{C}\right.$ e $20-30{ }^{\circ} \mathrm{C}$ ), dos métodos de superação de dormência (sem escarificação, escarificação mecânica, química e térmica) e dos estresses hídrico e salino nos potenciais osmóticos $(0,0 ;-0,2 ;-0,4$ e $-0,8 \mathrm{MPa})$. As variáveis avaliadas foram porcentagem de germinação, índice de velocidade de germinação e tempo médio de germinação. Os métodos de escarificação mecânica e química a 5, 15 e 30 min, foram eficientes para superar a dormência física, sobretudo nos regimes de temperatura constante de $25^{\circ} \mathrm{C}$ e $30{ }^{\circ} \mathrm{C}$ e alternada $20-30^{\circ} \mathrm{C}$. Sob condições de estresse hídrico e salino a germinação foi reduzida com o aumento do potencial osmótico, sendo -0,8 MPa o limite mínimo de germinação, além disso sementes foram mais sensíveis ao estresse hídrico do que ao estresse salino.

Termos para indexação: dormência de sementes, espécie pioneira, temperatura, estresse hídrico, estresse salino.
Journal of Seed Science, v.42, e202042033, 2020

http://dx.doi.org/10.1590/2317$1545 v 42238498$
*Corresponding author E-mail: jullyannacarvalho@gmail.com

Received: 5/22/2020. Accepted: 8/14/2020.

${ }^{1}$ Departamento de Agricultura, Universidade Federal de Lavras (UFLA), Lavras, MG, Brasil.

${ }^{2}$ Colegiado de Engenharia Agronômica, Universidade Federal do Vale do São Francisco (UNIVASF), Petrolina, PE, Brasil.

${ }^{3}$ Colegiado de Ciências Biológicas, Universidade Federal do Vale do São Francisco (UNIVASF), Petrolina, PE, Brasil. 


\section{INTRODUCTION}

Caatinga is the prevailing biome in the northeastern Brazilian semiarid, characterized by water deficit and excessive salts in the soil, it has a great diversity of vegetable species. Senna uniflora (Mill.) H.S.Irwin \& Barneby is a species of the family Fabaceae considered a Caatinga native plant (BFG, 2018). It is an annual herb, spontaneous, pioneer, with variable height from 0.5 to $0.8 \mathrm{~m}$ in function of the environment, and it spreads by seeds (Santos et al., 2020).

Plants of this species are frequently found in degraded areas of the Caatinga region and is potential for the recovery of those areas. Besides, they have a forage feature and are efficient as green manure, promoting the same effects of soil coverage, biomass production and cycling of nutrients as species introduced for green manure (Favero et al., 2010). This is because, the use of pioneer species of rapid growth facilitates the start of a successional experience, mainly by shading and incorporating nutrients, since, they cover the soil early incorporating organic matter and inhibiting the development of invasive alien species (Rodrigues et al., 2019).

The Fabaceae, in general, attracts great interest for the recovery of degraded areas, since they are able, mostly, to fix nitrogen from the atmosphere and contribute to the recovery of the soil, which provides more favorable conditions for the establishment of other species (Pereira et al., 2013). However, for the recovery plans of degraded areas, both by direct seeding and by planting with seedlings, it is necessary to know the aspects of species biology and ecology. The success of using direct sowing, a technique with lower cost and easier to operate than seedling planting, depends on the choice of adapted or tolerant species to local environmental conditions (Pereira et al., 2013).

In this sense, studies on the species germination are important to understand the species behavior in a given environment, once, in addition to the influence of seeds intrinsic factors on germination, sprouting can also be affected by environmental factors, such as water availability, salinity and temperature (Bewley et al., 2013). However, even submitted to favorable environmental conditions, viable and intact seeds may present incapacity of germination, phenomenon known as dormancy (Jaganathan, 2020). This condition of physiological inactivity favors the survival and perpetuation of species and to providing distribution of germination in time and space.

According to Bewley et al. (2013), the most recurrent type among vegetable species is the physical dormancy, which occurs in 15 Angiosperm families, being more frequent in Fabaceae. Inserted in this family, many Senna species have presented this dormancy, S. marilandica and S. obtusifolia (Baskin et al., 1998), S. multijuga (Rodrigues-Junior et al., 2014), S. pendula (Rodrigues-Filho et al., 2018) and S. macranthera (Cipriani et al., 2019).

Physical dormancy is caused by the impermeability of the palisade layer of seed tegument, which prevents imbibition and, consequently, the beginning of germination (Jaganathan, 2020). Amongst the methods usually employed for overcome physical dormancy in Fabaceae are the immersion in hot water, mechanical scarification, chemical scarification, and temperature alternation (Baskin and Baskin, 2014).

Thus, ecophysiology of seed germination is fundamental to understand the species behavior under certain environmental conditions, as well as, the establishment of ruderal species, its succession and natural regeneration. Moreover, it is an effective tool to explore native species, especially in Caatinga a poorly protected biome, where studies on germination are still scarce.

In this context, the aim of this study was to characterize, as well as assess the influence of different temperatures, methods of overcoming dormancy and the effects of water and salt stresses in the germination of $S$. uniflora.

\section{MATERIAL AND METHODS}

\section{Seed harvest}

Fruits of S. uniflora were harvested in 100 individuals of natural populations of Caatinga vegetation in July 2015,

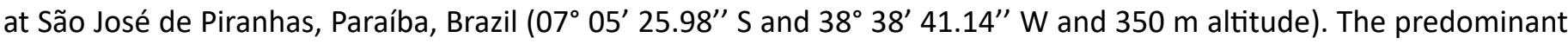
climate in the region is semiarid, hot and dry, of the BSh type according to Köppen, with average, minimal and maximum 
annual temperatures of $24.85^{\circ} \mathrm{C}, 20.11^{\circ} \mathrm{C}$ and $31.49^{\circ} \mathrm{C}$, respectively, and average annual rainfall of $923 \mathrm{~mm}$. After harvest, fruits were benefited, and seeds were stored in a cold chamber at a $10^{\circ} \mathrm{C}$ temperature until the start of the experiment.

Weight and moisture of seeds

The weight of 1,000 seeds with eight replications of 100 pure seeds from the harvested populations. Seeds moisture content was determined by the greenhouse method at $105^{\circ} \mathrm{C} \pm 3{ }^{\circ} \mathrm{C}$ for 24 hours. To this end, four replications of 25 seeds in aluminum crucibles with lids were used. Weighing was carried out in a precision analytical balance $(0.0001 \mathrm{~g})$, with results expressed in percentage (Brasil, 2009).

\section{Seed imbibition}

The imbibition experiment was conducted in order to assay the impermeability of seeds tegument to water, according to Baskin et al. (1998). Six treatments were carried out, without scarification (control); mechanical scarification (sandpaper $n^{\circ} 80$ ); chemical scarification (PA sulphuric acid) for $5 \mathrm{~min}, 15 \mathrm{~min}$ and $30 \mathrm{~min}$ and thermal scarification water at $80^{\circ} \mathrm{C}$ for $10 \mathrm{~min}$ (best time for seeds germination at $80^{\circ} \mathrm{C}$ according to preliminary assay), with four replications of 50 seeds. All treatments were put in Petri dishes over filter paper moist with distilled water, at room temperature. Seeds imbibition was measured after $0,1,2,4,8,12$ and 24 hours. In each imbibition measurement seeds were dried in absorbent paper, weighed in precision analytical balance $(0.0001 \mathrm{~g})$ and replaced in Petri dishes over moist filters. The quantity of water absorbed was determined from the real increase in seeds weight and converted to percentage.

\section{Effect of temperature and method of overcoming dormancy}

The seeds of S. uniflora were used to determine the effect of different temperatures and methods of overcoming dormancy on germination. All seeds were initially sterilized with $2 \%$ sodium hypochlorite for 3 minutes.

On the germination assay, seeds were subjected to six temperature regimes, five constant and one alternated: $20{ }^{\circ} \mathrm{C} ; 25^{\circ} \mathrm{C} ; 30{ }^{\circ} \mathrm{C} ; 35^{\circ} \mathrm{C} ; 40^{\circ} \mathrm{C}$ and $20-30{ }^{\circ} \mathrm{C}$ (submitted to photoperiod of 12 hours and continuous darkness) and six methods of overcoming dormancy: without scarification (control); mechanical scarification (sandpaper $\mathrm{n}^{\circ} 80$ ); chemical scarification (PA sulphuric acid) for $5 \mathrm{~min}, 15 \mathrm{~min}$ and $30 \mathrm{~min}$ and thermal scarification (water at $80^{\circ} \mathrm{C}$ for 10 $\mathrm{min}$ ). Seeds were then put in Petri dishes over two sheets of moist filter paper with distilled water, in the quantity of 2.5 times the paper weight, and incubated in germination chambers of the Biochemical Oxygen Demand type (B.O.D), with photoperiods of $12 \mathrm{~h}$ of light and $12 \mathrm{~h}$ of darkness, and relative humidity of $60 \%$. Distilled water was added to keep the substrate moist, according to necessity (Baskin et al., 1998). Germination was assessed daily for 30 days. Radicle protrusion was the criteria for germination (Catara et al., 2016).

The experiment was carried out in a completely randomized design, in a $6 \times 6$ factorial scheme (six temperatures and six methods of overcoming dormancy), with four replications of 100 seeds in each treatment. The variables determined were germination (G), with results expressed in percentage; germination speed index (GSI) (Maguire, 1962) and average germination time (AGT) (Labouriau, 1983), with results expressed in days.

\section{Effect of water and salt stresses on germination}

The seeds of S. uniflora were used to determine the effect of water and salt stresses on germination. All seeds were initially scarified with sulphuric acid (PA) for $5 \mathrm{~min}$ to overcome tegument dormancy, based on results of the previous experiment.

Water and salt stresses were simulated with the osmotic agent polyethylene glycol (PEG 6000) and sodium chloride $(\mathrm{NaCl})$, respectively, at osmotic potentials 0.0 (control), $-0.2,-0.4$, and $-0.8 \mathrm{MPa}$. Control corresponds to treatment with distilled water.

The determination of the quantities of PEG 6000 used in the preparation of water stress inducing solutions at the different osmotic potentials followed the methodology proposed by Villela et al. (1991). The quantities of $\mathrm{NaCl}(\mathrm{PM}$ 58.44) used in the preparation of solutions to induce salt stress were obtained from Van't Hoff's formula. 
Seeds were put in Petri dishes over two sheets of filter paper moist with solutions of PEG $6000, \mathrm{NaCl}$ or distilled water, at the different osmotic potential levels established, in a proportion equivalent to 2.5 times the weight of the dry substrate. Petri dishes were sealed with PVC film to avoid loss of humidity and the seeds were put to germinate in a B.O.D., at a constant temperature of $25^{\circ} \mathrm{C} \pm 1{ }^{\circ} \mathrm{C}$, photoperiod of $12 \mathrm{~h} / 12 \mathrm{~h}$ (light/darkness) and relative humidity of $60 \%$. Germination was assessed daily for 30 days. Radicle protrusion was the same criteria for germination (Catara et al., 2016).

The experiment was conducted in a completely randomized design, with treatments arranged in a $2 \times 4$ factorial structure (two osmotic agents and four osmotic potentials), and four replications of 100 seeds in each treatment. Variables determined were percentage of germination, with results expressed in percentage; germination speed index (Maguire, 1962) and average germination time (Labouriau, 1983), with results expressed in days.

\section{Statistical analysis}

Germination data were submitted to a variance analysis (ANOVA), through the $F$ test. Values of percentage of germination were transformed in arc sine and all data were verified regarding normality, trough Shapiro-Wilk test, before analysis. The means were compared by the Tukey test at a $5 \%$ probability, using the statistical program Sisvar ${ }^{\circledR}$.

\section{RESULTS AND DISCUSSION}

The seeds of $S$. uniflora are relatively small, being the weight of a thousand seeds, on average, $0.45 \pm 0.01 \mathrm{~g}$. Results on moisture suggest that seeds are orthodox, once they presented low moisture contents, $5.65 \pm 0.31 \%$. A recent study revealed that over $98 \%$ of the Fabaceae species have orthodox seeds (Jayasuriya et al., 2012). Corroborating, Abudureheman et al. (2014) identified orthodoxal behavior in seeds of 19 species of Fabaceae. Seeds of the species S. uniflora (Fabaceae) also presented low moisture content. Thus, results suggest that this species is orthodox and has high tolerance to desiccation.

The imbibition curve of seeds scarified chemically, thermally and mechanically, as well as non scarified, presented the same pattern, with gradual increase on the first 12 hours and stabilization after this period. Nonetheless, the weight of seeds submitted to mechanical and chemical scarification for $30 \mathrm{~min}, 15 \mathrm{~min}$ and $5 \mathrm{~min}$ increased $140 \pm 3.39 \%$, $126 \pm 1.62 \%, 126 \pm 4.17 \%$ and $70 \pm 4.52 \%$, respectively, while seeds submitted to thermal scarification and without scarification had their weights increased in $30 \pm 1.61 \%$ and $27 \pm 1.25 \%$, respectively (Figure 1 ). Thus, the imbibition

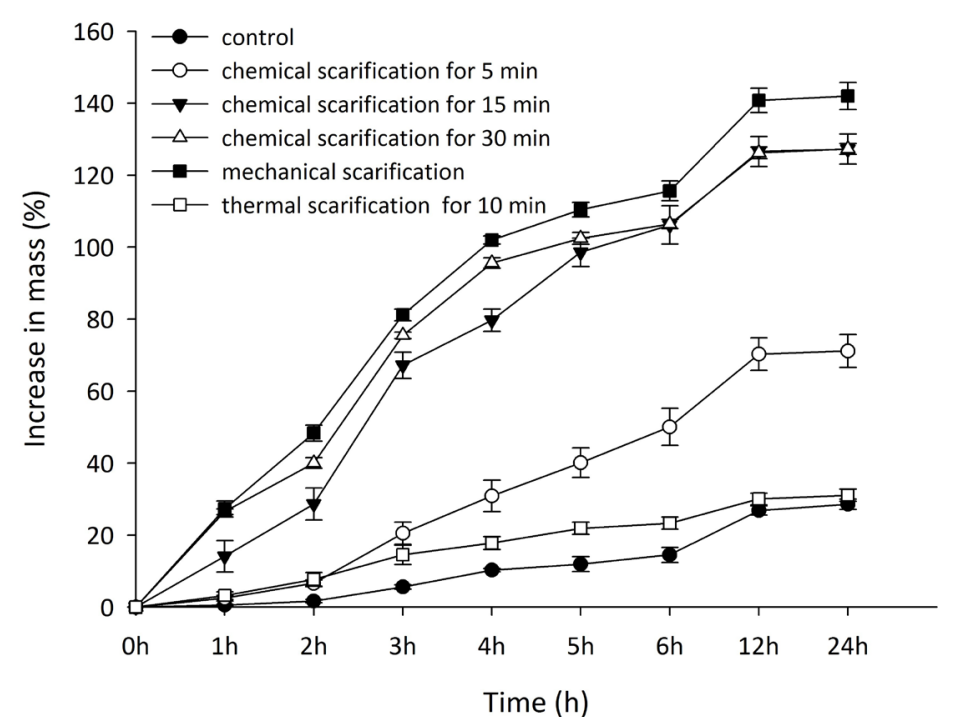

Figure 1. Percentage increase of seed mass $S$. uniflora (average \pm standard error, $n=4$ ) during imbibition at room temperature. 
process on seeds without scarification and with thermal scarification occurred in a reduced way when compared to chemically and mechanically scarified seeds, which presented rapid water absorption. This behavior demonstrates the low permeability of the seed's tegument to water, characterizing physical dormancy. Thus, the need to use pregerminative treatments to the occurrence of germination in S. uniflora seeds and to standardize the germinative process is verified.

This characteristic was also found in other Senna species, as S. marilandica and S. obtusifolia (Baskin et al., 1998), S. multijuga (Rodrigues-Junior et al., 2014), S. pendula (Rodrigues-Filho et al., 2018) and S. macranthera (Cipriani et al., 2019), in addition to 15 Fabaceae species (Abudureheman et al., 2014), since it is a common feature to this botanical family. According to Abudureheman et al. (2014), the imbibition of seeds is determined by species specific attributes and by the degree of seeds hardness. For that reason, are directly related to seeds moisture content.

The imbibition process in mechanical or chemical scarified S. uniflora seeds was notably more efficient when compared to seeds submitted to thermal scarification or without scarification, once the first ones increased their weights in over $100 \%$, while the last ones had increases inferior to $30 \%$ after 12 hours (Figure 1). Similar results were found by Baskin et al. (1998), in which the weight of scarified seeds of S. marilandica and S. obtusifolia had increases of $130 \%$ and $127 \%$, respectively, whereas non scarified seeds increased only $2.8 \%$ and $18.6 \%$, respectively. In the same way, Rodrigues-Filho et al. (2018) observed that the water absorption in seeds with manual or sulphuric acid scarifications is quite similar and superior to the absorption verified in the hot water treatment. S. multijuga scarified seeds also had significant increases in their weights, while non scarified seeds kept roughly the same weight after imbibition (Rodrigues-Junior et al., 2014).

Thus, the results suggest that $S$. uniflora seeds present a hydration resistance caused by the tegument, to which is attributed the physical dormancy phenomenon. A fact that has been reported for most of the leguminous plants (Baskin and Baskin, 2014). Seed dormancy is one of the main strategies used by plants to increase their survival rates and the establishment of young plants, as it allows germination to occur only submitted to favorable conditions (Jaganathan, 2020). Artificial overcoming of seeds dormancy induces a reduction in germination time and seedling emergence, which may result in less recruitment of young plants (Pereira et al., 2013). However, in areas with well-defined dry and rainy seasons, such as the Caatinga, according to Pereira et al. (2013), overcoming dormancy allows greater control of emergence time, which may decrease mortality rates due to desiccation and increase the time that emerged seedlings would have during the growing season, before the dry season, in addition to reducing seed exposure time to pathogens, pests and other predators.

There was a significant effect of the interaction between the factors temperature and method of overcoming dormancy $(p<0.05)$ for the variables percentage of germination $(G)$, average germination time (AGT) and germination speed index (GSI).

Through the unfolding analysis of the methods of overcoming dormancy within each temperature regime, at a $20^{\circ} \mathrm{C}$ and $30{ }^{\circ} \mathrm{C}$ constants temperatures, chemical scarification for $30 \mathrm{~min}$ was significantly superior to the other methods of overcoming dormancy, resulting in higher germination. At constant temperatures of $30{ }^{\circ} \mathrm{C}$ and alternate of $20-30{ }^{\circ} \mathrm{C}$, higher $\mathrm{Gs}$ were obtained using scarification methods, either mechanical or chemical $(5,15$ and $30 \mathrm{~min})$. At temperatures of $35^{\circ} \mathrm{C}$ and $40^{\circ} \mathrm{C}$, chemical scarification for 5 and 15 min had significantly higher Gs than the other methods. Besides, in all temperature regimes, except when seeds were incubated at alternated temperature of 20 $30{ }^{\circ} \mathrm{C}$, the method of water immersion at $80^{\circ} \mathrm{C}$ was the least efficient on overcoming dormancy, with lower $\mathrm{G}$, not differing statistically from the control (Table 1 ).

Analyzing the unfolding of temperature regimes within each method of overcoming dormancy, non treated seeds, had higher Gs when exposed to temperatures of $25^{\circ} \mathrm{C}, 30^{\circ} \mathrm{C}$ and $35^{\circ} \mathrm{C}$. When the method of mechanical scarification was used, temperature that provided higher $\mathrm{G}$ were $30^{\circ} \mathrm{C}$. Using chemical scarification for $5 \mathrm{~min}, 15 \mathrm{~min}$ and $30 \mathrm{~min}$, the $\mathrm{G}$ of seeds subjected to $25^{\circ} \mathrm{C}, 30^{\circ} \mathrm{C}$ and $20-30^{\circ} \mathrm{C}$ were significantly superior to the other temperatures. The method of thermal scarification had higher $\mathrm{Gs}$ at temperatures of $30{ }^{\circ} \mathrm{C}, 35^{\circ} \mathrm{C}$ and $20-30{ }^{\circ} \mathrm{C}$. In all methods of overcoming dormancy, except chemical scarification for $5 \mathrm{~min}$, the least efficient incubation temperature was of $40^{\circ} \mathrm{C}$ (Table 1 ). 
Concerning variable AGT, the best method of overcoming dormancy, that is the one with lower AGT, at constant temperature of $20^{\circ} \mathrm{C}$, was chemical scarification for $30 \mathrm{~min}$. At a $25^{\circ} \mathrm{C}$ temperature, chemical scarification for 5,15 and $30 \mathrm{~min}$ did not differ statistically from each other and had the lower AGTs. At constant temperatures of $30^{\circ} \mathrm{C}, 35^{\circ} \mathrm{C}, 40$ ${ }^{\circ} \mathrm{C}$ and alternated $20-30{ }^{\circ} \mathrm{C}$, methods of mechanical and chemical scarification for 5,15 and 30 min were significantly superior, resulting in lower AGTs. Thermal scarification was the method that resulted in longer AGT in all temperature regimes, not differing statistically from the control (Table 2).

The method of mechanical scarification indicated lower AGT at temperatures of $40{ }^{\circ} \mathrm{C}$ and $20-30{ }^{\circ} \mathrm{C}$. Chemical scarification for $5 \mathrm{~min}$ and $15 \mathrm{~min}$ were significantly superior at the temperature $20-30{ }^{\circ} \mathrm{C}$. Chemical scarification for 30 min presented longer AGT at $40{ }^{\circ} \mathrm{C}$ (4.04 days), differing from the other temperatures that were statistically equal and superior. The method of thermal scarification had lower AGT at $35^{\circ} \mathrm{C}$ (Table 2).

In respect of the variable $\mathrm{GSI}$, at constant temperatures of $20^{\circ} \mathrm{C}, 25^{\circ} \mathrm{C}, 30^{\circ} \mathrm{C}$ and $35{ }^{\circ} \mathrm{C}$, chemical scarification for 30 min was significantly superior to the other methods of overcoming dormancy, providing higher GSI s. At constant temperature of $40{ }^{\circ} \mathrm{C}$, methods of chemical scarification for 5,15 and $30 \mathrm{~min}$ did not differ statistically from each

Table 1. Germination (average \pm standard error, $n=4$ ) of Senna uniflora seeds, after 30 days of incubation, subjected to temperature regimes and method of overcoming dormancy.

\begin{tabular}{ccccccc}
\hline \multicolumn{7}{c}{ Germination (\%) } \\
\hline $\begin{array}{c}\text { Temperature } \\
\left({ }^{\circ} \mathrm{C}\right)\end{array}$ & Control & $\begin{array}{c}\text { Mechanical } \\
\text { scarification }\end{array}$ & $\begin{array}{c}\text { Chemical } \\
\text { scarification } \\
5 \mathrm{~min}\end{array}$ & $\begin{array}{c}\text { Chemical } \\
\text { scarification } \\
15 \mathrm{~min}\end{array}$ & $\begin{array}{c}\text { Chemical } \\
\text { scarification } \\
30 \mathrm{~min}\end{array}$ & $\begin{array}{c}\text { Thermal } \\
\text { scarification }\end{array}$ \\
\hline 20 & $30,34 \pm 2,43 \mathrm{Bd}$ & $80,40 \pm 3,32 \mathrm{BCb}$ & $55,35 \pm 2,23 \mathrm{Dc}$ & $77,05 \pm 5,22 \mathrm{Bb}$ & $90 \mathrm{Aa}$ & $32,70 \pm 1,36 \mathrm{bd}$ \\
25 & $32,68 \pm 1,56 \mathrm{ABc}$ & $86,07 \pm 2,43 \mathrm{ABab}$ & $82,21 \pm 1,37 \mathrm{Aab}$ & $79,22 \pm 1,72 \mathrm{Ab}$ & $90 \mathrm{Aa}$ & $34,27 \pm 1,00 \mathrm{Bc}$ \\
30 & $40,38 \pm 1,46 \mathrm{Ab}$ & $90 \mathrm{Aa}$ & $81,93 \pm 4,84 \mathrm{Aa}$ & $85,93 \pm 2,35 \mathrm{Aa}$ & $90 \mathrm{Aa}$ & $43,69 \pm 2,09 \mathrm{Ab}$ \\
35 & $40,94 \pm 2,18 \mathrm{Ac}$ & $62,23 \pm 0,86 \mathrm{Db}$ & $69,33 \pm 0,74 \mathrm{BCab}$ & $76,25 \pm 2,76 \mathrm{Ba}$ & $67,21 \pm 2,81 \mathrm{Bb}$ & $42,24 \pm 2,55 \mathrm{Ac}$ \\
40 & $28,25 \pm 1,45 \mathrm{Bc}$ & $55,74 \mathrm{~Eb}$ & $67,10 \pm 2,33 \mathrm{Ca}$ & $66,42 \pm 2,79 \mathrm{Ca}$ & $41,53 \pm 2,34 \mathrm{Cb}$ & $29,08 \pm 1,64 \mathrm{Cc}$ \\
$30 / 20$ & $32,55 \pm 1,18 \mathrm{ABc}$ & $76,80 \pm 0,63 \mathrm{Ca}$ & $77,56 \pm 1,14 \mathrm{Aba}$ & $82,01 \pm 0,87 \mathrm{Aa}$ & $82,60 \pm 1,03 \mathrm{Aa}$ & $43,27 \pm 1,97 \mathrm{Ab}$ \\
\hline
\end{tabular}

Means followed by the same letters, uppercase in the columns and lowercase in the lines, indicate no significant differences, according to Tukey test $(p<0,05)$.

Table 2. Average germination time (average \pm standard error, $n=4$ ) of Senna uniflora seeds, of Senna uniflora seeds, after 30 days of incubation, subjected to temperature regimes and method of overcoming dormancy.

\begin{tabular}{ccccccc}
\hline \multicolumn{7}{c}{ Average germination time (days) } \\
\hline $\begin{array}{c}\text { Temperature } \\
\left({ }^{\circ} \mathrm{C}\right)\end{array}$ & Control & $\begin{array}{c}\text { Mechanical } \\
\text { scarification }\end{array}$ & $\begin{array}{c}\text { Chemical } \\
\text { scarification } \\
5 \text { min }\end{array}$ & $\begin{array}{c}\text { Chemical } \\
\text { scarification } \\
15 \mathrm{~min}\end{array}$ & $\begin{array}{c}\text { Chemical } \\
\text { scarification } \\
30 \mathrm{~min}\end{array}$ & $\begin{array}{c}\text { Thermal } \\
\text { scarification }\end{array}$ \\
\hline 20 & $10,27 \pm 1,60 \mathrm{Aa}$ & $3,56 \pm 0,87 \mathrm{Abc}$ & $4,16 \pm 0,63 \mathrm{Abc}$ & $3,49 \pm 0,72 \mathrm{ABc}$ & $1,10 \pm 0,03 \mathrm{Bd}$ & $7,92 \pm 1,51 \mathrm{ABb}$ \\
25 & $9,94 \pm 0,95 \mathrm{Aa}$ & $4,85 \pm 0,56 \mathrm{Abc}$ & $2,06 \pm 0,24 \mathrm{BCd}$ & $3,12 \pm 0,26 \mathrm{ABcd}$ & $1,02 \pm 0,01 \mathrm{Bd}$ & $6,92 \pm 0,85 \mathrm{ABb}$ \\
30 & $7,14 \pm 0,93 \mathrm{Ba}$ & $2,52 \pm 0,23 \mathrm{BCb}$ & $2,74 \pm 0,16 \mathrm{ABCb}$ & $1,77 \pm 0,09 \mathrm{BCb}$ & $1,03 \pm 0,01 \mathrm{Bb}$ & $7,08 \pm 0,36 \mathrm{Aba}$ \\
35 & $6,63 \pm 0,23 \mathrm{Ba}$ & $1,95 \pm 0,02 \mathrm{BCb}$ & $1,97 \pm 0,01 \mathrm{BCb}$ & $1,99 \pm 0,09 \mathrm{BCb}$ & $1,62 \pm 0,07 \mathrm{Bb}$ & $5,70 \pm 0,33 \mathrm{Ca}$ \\
40 & $5,97 \pm 0,04 \mathrm{Ba}$ & $3 \mathrm{ABCb}$ & $4,86 \pm 0,02 \mathrm{Aab}$ & $4,96 \pm 0,01 \mathrm{Aab}$ & $4,04 \pm 0,06 \mathrm{Aab}$ & $5,74 \pm 0,13 \mathrm{Ba}$ \\
$30 / 20$ & $5,37 \pm 0,70 \mathrm{Ba}$ & $1,09 \pm 0,02 \mathrm{Cb}$ & $1,02 \mathrm{Cb}$ & $1,00 \mathrm{Cb}$ & $1,00 \mathrm{Bb}$ & $8,12 \pm 0,57 \mathrm{Aa}$ \\
\hline
\end{tabular}

Means followed by the same letters, uppercase in the columns and lowercase in the lines, indicate no significant differences, according to Tukey test $(p<0,05)$. 
other and were superior to others. At the alternate temperature of $20-30{ }^{\circ} \mathrm{C}$, methods of mechanical and chemical scarification for 5, 15 and $30 \mathrm{~min}$ had the highest GSIs and had no statistical difference from each other. As well as for the variables $G$ and $A G T$, thermal scarification was also the method that presented the worst results, not differing statistically from the control (Table 3).

The methods of mechanical and chemical scarification for 5 min presented the highest GSIs at the alternate temperature $20-30{ }^{\circ} \mathrm{C}$. The methods of chemical scarification for 15 and 30 min exhibited GSI and statistically equal at the temperatures of $20^{\circ} \mathrm{C}, 25^{\circ} \mathrm{C}, 30^{\circ} \mathrm{C}$ and $20-30{ }^{\circ} \mathrm{C}$. The thermal scarification had higher GSIs when incubated at temperatures of $25{ }^{\circ} \mathrm{C}, 30^{\circ} \mathrm{C}, 35^{\circ} \mathrm{C}$ and $20-30{ }^{\circ} \mathrm{C}$. In all the methods of overcoming dormancy assessed, the lower GSI was related to the $40^{\circ} \mathrm{C}$ temperature (Table 3).

In general, in S. uniflora seeds, the methods of mechanical and chemical scarification for 5, 15 and 30 min showed more efficacy in breaking dormancy, providing higher percentage of germination, lower average germination time and higher germination speed index. Mechanical and chemical scarification methods have been the most efficient on breaking physical dormancy of Fabaceae species, as reported by Abudureheman et al. (2014). However, it is highlighted that the efficiency of chemical scarification is related to the exposure time to the acid, as well as to the species itself (Albuquerque et al., 2007). Moreover, excessive mechanical scarification may cause damage to the embryo and decrease germination (Baskin and Baskin, 2014).

Previous studies have shown that both mechanical and chemical scarification increase the percentage of germination of Senna species, for example, S. marilandica and S. obtusifolia (Baskin et al., 1998), S. macranthera (Pozitano and Rocha, 2011), S. multijuga (Rodrigues-Junior et al., 2014), S. macranthera and S muntijuga (Pereira et al., 2014b) and S. pendula (Rodrigues-Filho et al., 2018).

In contrast, with the thermal scarification method, S. uniflora seeds not only presented a low percentage of germination but also took longer to germinate (Tables 1, 2 and 3). Similar behavior was observed by Cipriani et al. (2019), who using hot water in S. macranthera obtained lower germination percentage, when compared to other methods. That is because the exposure to elevated temperatures may affect embryo tissues and damage the seeds of some species causing mortality (Felix et al., 2020).

On the other hand, this method shows positive results in seeds of S. multijuga (Rodrigues-Junior et al., 2014). Baskin et al. (1998) noted that, despite hot water being efficient in breaking the dormancy of S. marilandica and S. obtusifolia, when seeds were immersed for a period equal or superior to 20 seconds, there was a decrease in germination.

In addition to the mentioned methods of overcoming dormancy, according to Baskin and Baskin (2014), alterations

Table 3. Germination speed index (average \pm standard error, $n=4$ ) of Senna uniflora seeds, of Senna uniflora seeds, after 30 days of incubation, subjected to temperature regimes and method of overcoming dormancy.

\begin{tabular}{ccccccc}
\hline \multicolumn{7}{c}{ Germination speed index } \\
\hline $\begin{array}{c}\text { Temperature } \\
\left({ }^{\circ} \mathrm{C}\right)\end{array}$ & Control & $\begin{array}{c}\text { Mechanical } \\
\text { scarification }\end{array}$ & $\begin{array}{c}\text { Chemical } \\
\text { scarification } \\
5 \text { min }\end{array}$ & $\begin{array}{c}\text { Chemical } \\
\text { scarification } \\
15 \mathrm{~min}\end{array}$ & $\begin{array}{c}\text { Chemical } \\
\text { scarification } \\
30 \mathrm{~min}\end{array}$ & $\begin{array}{c}\text { Thermal } \\
\text { scarification }\end{array}$ \\
\hline 20 & $7,31 \pm 0,90 \mathrm{Ad}$ & $63,47 \pm 4,33 \mathrm{Bb}$ & $45,13 \pm 1,43 \mathrm{Cc}$ & $46,22 \pm 2,11 \mathrm{Ac}$ & $95,00 \pm 1,74 \mathrm{Aa}$ & $11,28 \pm 0,62 \mathrm{Cd}$ \\
25 & $8,88 \pm 0,67 \mathrm{ABd}$ & $66,66 \pm 2,28 \mathrm{Bc}$ & $76,15 \pm 1,70 \mathrm{Bb}$ & $69,44 \pm 2,21 \mathrm{Abc}$ & $99,00 \pm 0,35 \mathrm{Aa}$ & $15,18 \pm 0,82 \mathrm{Bd}$ \\
30 & $15,01 \pm 2,33 \mathrm{Ad}$ & $67,34 \pm 2,60 \mathrm{Bc}$ & $60,62 \pm 3,59 \mathrm{Bc}$ & $75,12 \pm 2,84 \mathrm{Ab}$ & $98,75 \pm 0,52 \mathrm{Aa}$ & $22,52 \pm 1,24 \mathrm{Ad}$ \\
35 & $19,28 \pm 0,50 \mathrm{ABd}$ & $41,92 \pm 0,68 \mathrm{Cc}$ & $45,13 \pm 0,31 \mathrm{Cbc}$ & $49,88 \pm 3,16 \mathrm{Bb}$ & $59,25 \pm 4,87 \mathrm{Ba}$ & $20,76 \pm 0,96 \mathrm{Ad}$ \\
40 & $3,79 \pm 0,37 \mathrm{Bb}$ & $0,33 \mathrm{Db}$ & $17,61 \pm 0,60 \mathrm{Da}$ & $16,92 \pm 0,67 \mathrm{Ca}$ & $12,13 \pm 1,12 \mathrm{Ca}$ & $4,21 \pm 0,40 \mathrm{Cb}$ \\
$30 / 20$ & $11,07 \pm 1,68 \mathrm{Ab}$ & $91,23 \pm 0,51 \mathrm{Aa}$ & $94,50 \pm 0,84 \mathrm{Aa}$ & $98,00 \pm 0,41 \mathrm{Aa}$ & $98,25 \pm 0,48 \mathrm{Aa}$ & $19,90 \pm 2,83 \mathrm{Ab}$ \\
\hline
\end{tabular}

Means followed by the same letters, uppercase in the columns and lowercase in the lines, indicate no significant differences, according to Tukey test $(p<0,05)$. 
in dormancy states may also be induced by continuous exposure to low or high temperatures. For $S$. uniflora seeds, the percentage of germination and germination speed index were significantly higher at constant temperatures of $25^{\circ} \mathrm{C}$ and $30{ }^{\circ} \mathrm{C}$ and alternated $20-30^{\circ} \mathrm{C}$, in all the assessed methods of overcoming dormancy (mechanical scarification, chemical scarification for 5, 15 and 30 min and thermal scarification) and also in the control. According to Bewley et al. (2013), the influence of temperature in percentage and in final velocity of germination occurs because biochemical reactions and their enzymatic systems present specific thermal requirements.

Overall, there was a tendency of higher percentage values being associated with higher germination speed indexes. This same behavior was observed by Albuquerque et al. (2007) in B. virgilioides seeds, indicating a direct relation between both variables. The lower average germination time was achieved using the $20-30{ }^{\circ} \mathrm{C}$ alternated temperature. The stress imposed by temperature alternation is a way of decreasing the number of dormant seeds in leguminous plants, what may have accelerated the germination process. Besides, seeds are commonly subjected to temperature fluctuations when in natural conditions and, for some species, this variation is enough to break the tegumentar dormancy (Bewley et al., 2013).

In a previous research, in $S$. marilandica, non scarified seeds did not germinate, while scarified ones had high percentage of germination at alternated temperatures of $20-10{ }^{\circ} \mathrm{C}$ and $40-25^{\circ} \mathrm{C}$ (Baskin et al., 1998). Still according to the author, non scarified seeds of $S$. obtusifolia germinated in a significantly higher percentage than the seeds of $S$. marilandica, in the highest temperature regimes $\left(35-20^{\circ} \mathrm{C}, 40-25^{\circ} \mathrm{C}\right)$.

The interaction between the factors osmotic agents and osmotic potentials was significant, in all the assessed variables (G, GSI and AGT) for the species $S$. uniflora. Seeds of $S$. uniflora subjected to water and salt stresses showed a decrease in $\mathrm{G}$, in function of the reduction of the osmotic potentials. Osmotic agents PEG and $\mathrm{NaCl}$ at $-0,2 \mathrm{MPa}$ decreased $\mathrm{G}$ in $43.56 \%$ and $14.63 \%$, respectively, when compared to the control. At the osmotic potential of $-0.4 \mathrm{MPa}$ this reduction was of $60.88 \%$ and $47.62 \%$ in relation to the control, with the use of PEG and $\mathrm{NaCl}$, respectively. At -0.8 $\mathrm{MPa}$, both osmotic agents completely inhibited germination (Figure $2 \mathrm{~A}$ ). Similar results were seen for the variable GSI (Figure 2B). AGT, at an osmotic potential of $-0.2 \mathrm{MPa}$, was 0.24 days superior, and practically equal to the control, using PEG and $\mathrm{NaCl}$, respectively. At $-0.4 \mathrm{MPa}$, the inverse occurred, seeds in PEG and $\mathrm{NaCl}$ solutions presented, respectively, AGT similar and 0.31 days more than control (Figure 2C).

Comparing both osmotic agents, it was verified that at osmotic potentials of $-0.2 \mathrm{MPa}$ and $-0.4 \mathrm{MPa}$ the $\mathrm{G}$ of seeds submitted to PEG solution (45.86\% and $31.78 \%$ ) was significantly smaller when compared to the $\mathrm{G}(69.61 \%$ and $42.70 \%)$ of seeds submitted to $\mathrm{NaCl}$ (Figure 2A). The same fact was verified for GSI results (Figure 2B). Concerning AGT, at -0.2 $\mathrm{MPa}$, seeds in PEG germinated significantly faster than in $\mathrm{NaCl}$, that is, 1.43 and 1.16 days, respectively. At $-0.4 \mathrm{MPa}$, the time spent to germinate was of 1.16 and 1.50 days in solutions of PEG and $\mathrm{NaCl}$, respectively (Figure 2C). Moreover, it was observed that the differences in germination between osmotic agents decreased as the potentials became more neAGTive, being of $28.93 \%, 13.25 \%$ and null, at potentials of $-0.2 \mathrm{MPa},-0.4 \mathrm{MPa}$ and $-0.8 \mathrm{MPa}$, respectively. Thus, it is inferred that the species $S$. uniflora is more sensitive to water stress than to salt stress.

Submitted to conditions of water and salt stresses, the decrease in osmotic potential, that is, the increase in water restriction, significantly affected all the analyzed variables. S. uniflora seeds presented a gradual reduction of G and GSI, as well as an increase followed by decline in AGT, when the osmotic potentials of PEG and $\mathrm{NaCl}$ solutions were reduced from -0.2 to -0.8. Similar behavior was verified in S. obtusifolia (Pereira et al., 2014a), S. multijuga, S. maccranthera and Mimosa bimucronata (Santarém et al., 1996).

These facts may be explained by the decreased activity of some enzymes and, consequently, of the seeds metabolism, in function of a smaller water availability for digestion and transportation of reserve substances, being those processes characterized by a three-phase pattern of germination (Bewley et al., 2013). Thus, as the osmotic potential of the medium becomes more neAGTive, an inhibition/reduction of both percentage and germination velocity may occur, with wide variation of responses between species, from the extremely sensitive ones to the most resistants (Bewley et al., 2013). Munns (2002) added that, in the case of salinity, the decrease/inhibition of germination is due both to the osmotic effect, that is, the "physiological drought", as to the toxic effect resultant of ions concentration in the protoplasm. 

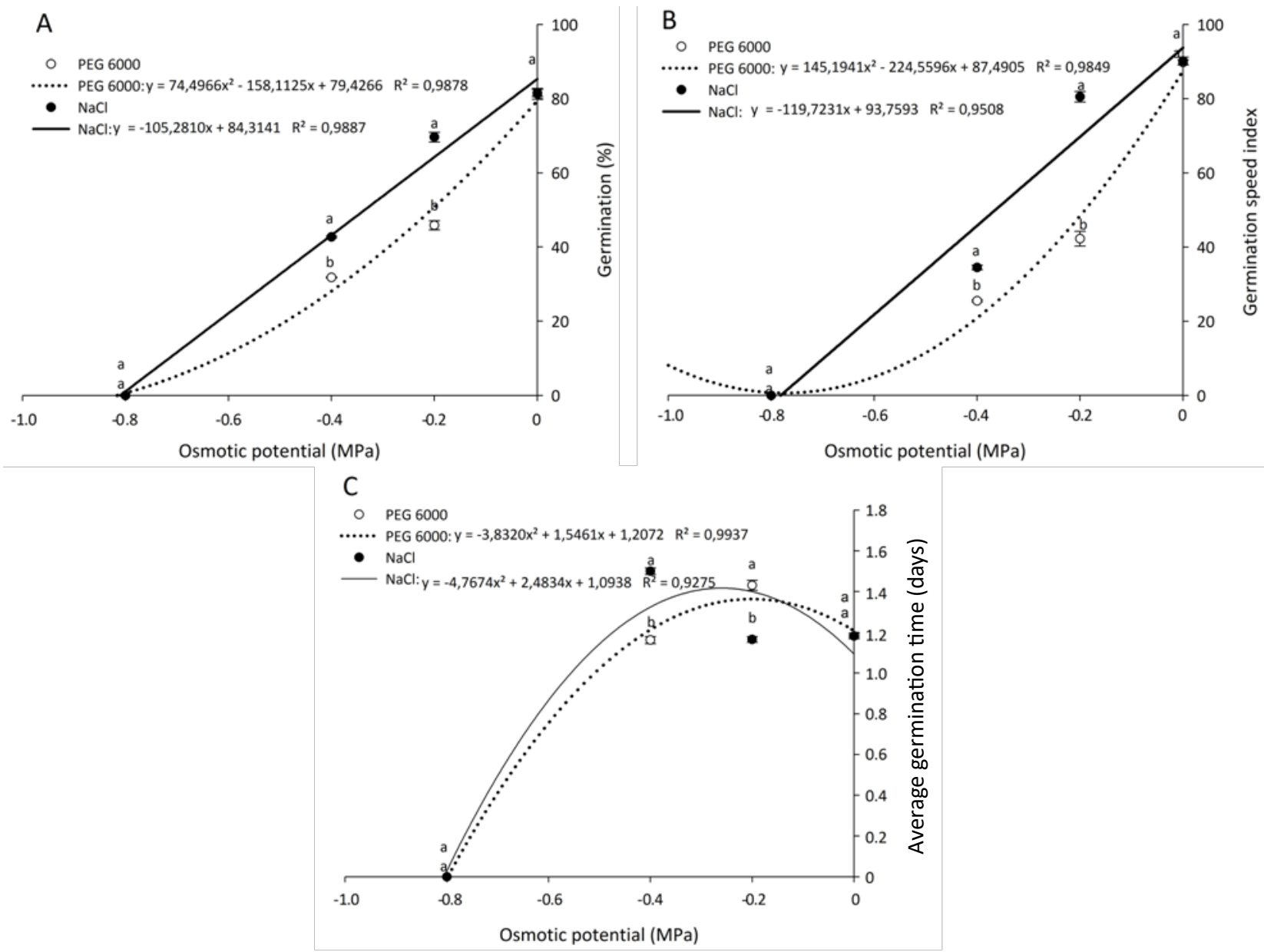

Figure 2. Germination (A), Germination speed index (B) e average germination time (C) (average \pm standard error, $\mathrm{n}=4$ ) of Senna uniflora seeds submited to water stress induced by PEG 6000 and salt stress induced by $\mathrm{NaCl}$ in different osmotic potentials. The same letters vertically indicate no significant differences, according to Tukey test $(p<0,05)$.

S. uniflora seeds presented significantly lower $\mathrm{G}$ and $\mathrm{GSI}$ when submitted to PEG solution than to $\mathrm{NaCl}$ solution, at the osmotic potentials of -0.2 and $-0.4 \mathrm{MPa}$. However, at $-0.8 \mathrm{MPa}$ germination was completely inhibited, regardless of the osmotic agent used. These results indicate a tolerance limit to water and salt stresses between the potentials of -0.2 and $-0.8 \mathrm{MPa}$. The percentage of germination diminishes with the decrease of the osmotic potential, and there is a critical value for each species, below which germination will not occur.

Similar results were found in S. obtusifolia by Pereira et al. (2014a), which verified the minimum limit of germinability at $-0.4 \mathrm{MPa}$, and that there was no more germination at -0.8 MPa for neither of the agents used. Smaller tolerance was cited by Norsworthy and Oliveira (2005) in S. occidentalis, which germinated until the potential of $-0.4 \mathrm{MPa}$. In contrast, higher tolerance limits were identified in S. macranthera, S. multijuga and M. bimucronata (-1.03 MPa) (Santarém et al., 1996).

It is then understood that the species S. uniflora presents higher sensitivity to water stress than to salt stress. A fact also observed in S. obtusifolia (Pereira et al., 2014a) and Senna ocidentalis (Norsworthy and Oliveira, 2005). According to Munns (2002), high solubility salts, as $\mathrm{NaCl}$, have lesser influence on the "physiological drought" than PEG, that is because seeds absorb salt together with water from the substrate, which causes a decrease in the cellular osmotic potential and, therefore, stimulate water absorption by seeds to maintain the water potential gradient between the seed and the substrate. In contrast, PEG molecules are relatively big to cross the cellular walls and, thus, are not 
absorbed by seeds, hence causing a higher water stress (Bewley et al., 2013).

The ecophysiological characteristics of S. uniflora, presented in this study, allow us to say that it is a species with potential for recovery degraded areas, mainly, for primary succession, due the specie presents functional attributes (early reproductive maturity, high production of fruits and seeds, seedlings with low nutritional requirements) for colonization of areas with soil exposed by the anthropic action. As an orthodox species, this trait is important because it allows its survival in the face of environmental stresses and can remain viable in the environment for a long period and resume its metabolism when there are ideal germination conditions. The presence of seed dormancy is interesting because the germination may occur at different times, thus reducing the initial competitiveness and may form a seed bank in the soil. But there is also the possibility of using treatments to overcome dormancy in order to aid in the germination process, contributing to a fast and uniform germination. In direct seeding, dormant seeds tend to take time to germinate and emerge, but the overcoming dormancy can decrease the time and increase the emergence rate, thus increase the efficiency of direct seeding in recovery degraded areas. Another significant feature of the species is resistance to water stress since climatic factors cannot be controlled. Thus, this drought tolerance is an important attribute for survival, especially in recovery plans in semi-arid regions of Northeastern Brazil.

\section{CONCLUSIONS}

This study shows that the species $S$. uniflora presents physical dormancy. Methods of mechanical and chemical scarification for 5, 15 and $30 \mathrm{~min}$ are efficient to overcome physical dormancy, specially on constant temperature regimes of $25^{\circ} \mathrm{C}$ and $30^{\circ} \mathrm{C}$ and alternated $20-30{ }^{\circ} \mathrm{C}$. Moreover, the species is resistant to water and salt stresses, with maximum tolerance limit at the osmotic potential of $-0.8 \mathrm{MPa}$, for both $\mathrm{PEG}$ and $\mathrm{NaCl}$. A higher sensitivity to water stress than to salt stress was also checked. This indicates the species potential to recuperation of the Caatinga areas, where there is a predominance of saline soils and dry season, once the success of using direct seeding depends on the choice of adapted or tolerant species to local environmental conditions, being it recommended near the rainy season.

\section{REFERENCES}

ABUDUREHEMAN, B.; LIU, H.; ZANGH, D.; GUAN, K. Identification of physical dormancy and dormancy release patterns in several species (Fabaceae) of the cold desert, north-west China. Seed Science Research, v.24, n.2, p.133-145, 2014. https://doi.org/10.1017/ S0960258514000063

ALBUQUERQUE, K.S.; GUIMARÃES, R.M.; ALMEIDA, I.F.; CLEMENTE, A.D S. Methods for dormancy overcoming of black sucupira (Bowdichia virgilioides Kunth.) seeds. Ciência e Agrotecnologia, v.31, n.6, p.1716-1721, 2007. https://doi.org/10.1590/S141370542007000600017

BASKIN, C.C.; BASKIN, J.M. Seeds. Ecology, biogeography, and evolution of dormancy and germination. 2 ed. London: Academic Press, 2014. 1600p.

BASKIN, J.M.; NAN, X.; BASKIN, C.C. A comparative study of seed dormancy and germination in an annual and a perennial species of Senna (Fabaceae). Seed Science Research, v.8, n.4, p.501-512, 1998. https://doi.org/10.1017/S0960258500004475

BEWLEY, J.D.; BRADFORD, K.; HILHORST, H. Seeds: Physiology of Development, Germination and Dormancy. 3 ed. New York: Springer, 2013. 408p.

BFG. THE BRAZIL FLORA GROUP. Brazilian Flora 2020: Innovation and collaboration to meet Target 1 of the Global Strategy for Plant Conservation (GSPC). Rodriguésia, v.69, n.4, p.1513- 1527, 2018. https://doi.org/10.1590/2175-7860201566411

BRASIL. Ministério da Agricultura, Pecuária e Abastecimento. Regras para análise de sementes. Ministério da Agricultura, Pecuária e Abastecimento. Secretaria de Defesa Agropecuária. Brasília: MAPA/ACS, 2009. 395p. https://www.gov.br/agricultura/pt-br/ assuntos/insumos-agropecuarios/arquivos-publicacoes-insumos/2946_regras_analise_sementes.pdf

CATARA, S.; CRISTAUDO, A.; GUALTIERI, A.; GALESI, R.; IMPELLUSO, C.; ONOFRI. A. Threshold temperatures for seed germination in nine species of Verbascum (Scrophulariaceae). Seed Science Research, v.26, n.1, p.30-46, 2016. https://doi.org/10.1017/ S0960258515000343 
CIPRIANI, V.B.; GARLET, J.; LIMA, B.M. Quebra de dormência em sementes de Chloroleucon acacioides e Senna macranthera. Revista de Ciências Agrárias, v.42, n.1, p.42054, 2019. http://dx.doi.org/10.19084/RCA18238

FAVERO, C. I.; COSTA, L. M.; ALVARENGA, R.C.; NEVES, J.C.L. Crescimento e acúmulo de nutrientes por plantas espontâneas e por leguminosas utilizadas para adubação verde. Revista Brasileira de Ciência do Solo, v.24, p.171-177, 2010. https://doi.org/10.1590/ S0100-06832000000100019.

FELIX, F.F.; MEDEIROS, J.A.D.; FERRARI, C.S.; PACHECO, M.V.; TORRES, S.B. Molecular aspects during seed germination of Erythrina velutina Willd. under different temperatures (Part 2): isoenzyme activity and DNA integrity. Journal of Seed Science, v.42, e202042030, 2020. http://dx.doi.org/10.1590/2317-1545v42234879

JAGANATHAN, G K. Do Fabaceae species with physical dormancy occur mostly in the temperate ecosystems? A rebuttal to using global biodiversity information facility (GBIF) analysis. Plant Science Today, v.7, n.1, p.109-111, 2020. https://doi.org/10.14719/pst.2020.7.1.646

JAYASURIYA, G.K.M.G.; WIJETUNGA, A.S.T.B.; BASKIN, J.M.; BASKIN, C.C. Physiological epicotyl dormancy and recalcitrant storage behaviour in seeds of two tropical Fabaceae (subfamily Caesalpinioideae) species. AoB Plants, v.44, p.1-10, 2012. https://doi. org/10.1093/aobpla/pls044

LABOURIAU, L.G. A germinação das sementes. Washington: Secretaria da OEA, 1983. 173p.

MAGUIRE, J.D. Speed of germination-aid in relation evaluation for seedling emergence vigor. Crop Science, v.2, n.2, p.176-177, 1962. http://dx.doi.org/10.2135/cropsci1962.0011183X000200020033x

MUNNS, R. Comparative physiology of salt and water stress. Plant, Cell \& Environment, v.25, n.2, p. 239-250, 2002. https://doi. org/10.1046/j.0016-8025.2001.00808.x

NORSWORTHY, J.K.; OLIVEIRA, M.J. Coffee senna (Cassia occidentalis) germination and emergence is affected by environmental factors and seedling depth. Weed Science, v.53, n.5, p.657-662, 2005. https://doi.org/10.1614/WS-04-209R.1

PEREIRA, M.R.R.; MARTINS, C.C.; MARTINS, D.; SILVA, R.J.N. Estresse hídrico induzido por soluções de PEG e de NaCl na germinação de sementes de nabiça e fedegoso. Bioscience Journal, v.30, n.3, p.687-696, 2014a. http://www.seer.ufu.br/index.php/ biosciencejournal/article/view/18049

PEREIRA, S. R.; LAURA, S. A.; SOUZA, A. L. T. Superação de dormência de sementes como estratégia para restauração florestal de pastagem tropical. Pesquisa Agropecuária Brasileira, v.48, n.2, p.148-156, 2013. http://dx.doi.org/10.1590/S0100-204X2013000200004

PEREIRA, V. J.; SANTANA, D. G.; LOBO, G. A.; BRANDÃO, N. A. L.; SOARES, D.C.P. Eficiência dos tratamentos para a superação ou quebra de dormência de sementes de Fabaceae. Revista de Ciências Agrárias, v.37, n.2, p.187-197, 2014b. http://www.scielo.mec. pt/scielo.php?script=sci_arttext\&pid=S0871-018X2014000200009

POZITANO, M.; ROCHA, S. C.S. Caracterização física e germinação de sementes de Senna macranthera. Revista Brasileira de Sementes, v.33, n.4, p.777-784, 2011. https://doi.org/10.1590/S0101-31222011000400020

RODRIGUES-FILHO, J.; CORTE,V.B.; PERIN, I.T.A.L. Dormancy breaking in Senna Pendula (Willd.) H. S. Irwin \& Barneby. Floresta e Ambiente, v.26, n.1, p.1-10, 2018. http://dx.doi.org/10.1590/2179-8087.000217

RODRIGUES-JUNIOR, A.G.; FARIA, J.M.R.; VAZ, T.A.A.; NAKAMURA, A.T.; JOSÉ, A.C. Physical dormancy in Senna multijuga (Fabaceae: Caesalpinioideae) seeds: the role of seed structures in water uptake . Seed Science Research, v.24, n.2, p. 147-157, 2014. https:// doi.org/10.1017/S0960258514000087

RODRIGUES, S.B.; FREITAS, M.G.; CAMPOS FILHO, E.M.; CARMO, G.H.P.; VEIGA, J.M.; JUNQUEIRA, R.G.P.; VIEIRA, D.L.M. Direct seeded and colonizing species guarantee successful early restoration of South Amazon forests. Forest Ecology and Management, v.451, n.1, 2019. https://doi.org/10.1016/j.foreco.2019.117559

SANTARÉM, E.R. CORTEZ, J. S. A.; SILVEIRA, T. S.; SILVEIRA, A. G. Efeito do estresse hídrico na germinação e crescimento inicial de três espécies de leguminosas. Acta Botanica Brasilica, v.10, n.2, p.213-221, 1996. http://dx.doi.org/10.1590/s0102-33061996000200002

SANTOS, T.T.; OLIVEIRA, A.C.S.; QUEIROZ, R.T.; SILVA, J.S. O gênero Senna (Leguminosae-Caesalpinioideae) no município de Caetité, Bahia, Brasil. Rodriguésia, v.71, p.1-17, 2020. https://doi.org/10.1590/2175-7860202071002

VILLELA, F.M.; DONI FILHO, L.; SEQUEIRA, E.L. Tabela de potencial osmótico em função da concentração de polietileno glicol 6000 e da temperatura. Pesquisa Agropecuária Brasileira, v.26, n.11, p.1957-1968, 1991. https://seer.sct.embrapa.br/index.php/pab/ article/view/3549/882 use, distribution, and reproduction in any medium, provided the original work is properly cited. 